\title{
PLASMINOGEN AND ANGIOSTATIN LEVELS IN FEMALE BENIGN BREAST LESIONS
}

\author{
A. A. TYKHOMYROV, I. L. VOVCHUK², T. V. GRINENKO \\ ${ }^{1}$ Palladin Institute of Biochemistry, National Academy of Sciences of Ukraine, Kyiv; \\ ${ }^{2}$ Odessa I. I. Mechnikov National University, Ukraine; \\ e-mail: artem_tykhomyrov@ukr.net
}

It is known that benign breast tissue exhibit relatively low angiogenic capacity. Activation of angiogenesis in mammary pre-malignant lesions could be associated with disease progression and high risk of transformation into the breast cancer. However, insight into the underlying molecular mechanisms involved in angiogenesis regulation in non-cancerous breast pathologies is still poorly defined. The purpose of the present study was to determine levels of plasminogen and its proteolytic fragments (angiostatins) in mammary dysplasia (mastopathy and breast cyst) and benign neoplasms (fibroadenomas). Plasminogen and angiostatins were analyzed using immunoblotting and quantified by densitometric scanning. The significant increase in plasminogen levels was found in fibrocystic, cysts, and non-proliferatious fibroadenoma masses (4.7-, 3.7-, and 3.5-fold, respectively) compared to healthy breast tissues (control). In the same benign lesions, 6.7-, 4-, and 3.7-fold increase in plasminogen $50 \mathrm{kDa}$ fragment (angiostatin) levels as compared with control were also observed. Activation of matrix metalloproteinase-9, which was detected using gelatine zymography, could be responsible for plasminogen cleavage and abundance of angiostatin in fibrocystic and cyst masses. In contrast, dramatic decrease of both plasminogen and angiostatin levels (3.8- and 5.3-folds, respectively) was shown in tissues of proliferatious form of fibroadenoma in comparison with that of the dormant type of this neoplasm. Based on the obtained results, we concluded that angiostatin, a potent vessel growth inhibitor and anti-inflammatory molecule, can play a crucial role in pathophysiology of non-cancerous breast diseases. Further studies are needed to evaluate potential diagnostic and clinical implications of these proteins for prediction and therapy of benign breast pathologies.

Key words: plasminogen, angiostatin, matrix metalloproteinases, angiogenesis, benign breast diseases, mastopathy, breast cyst, fibroadenoma.

$\mathrm{T}$ he term "benign breast diseases" (BBDs) encompasses a heterogeneous group of lesions, including developmental abnormalities, inflammatory lesions, epithelial and stromal proliferations, and neoplasms. Mastopathy (fibrocystic disease), breast cysts, and fibroadenoma are recognized to be the most prevalent types of BBDs [1]. According to the definition published by the World Health Organization (WHO) in 1984, mastopathy is the fibrocystic disease of breast, characterized by a disbalance between epithelial and connective tissues growth with high proliferative and regressive changes of the breast tissue [2]. Cysts are non-proliferative benign breast conditions, associated with hormone-dependent transformation of apocrine epithelial cells [3]. Fibroadenoma is the most common benign neoplasm of the breast. It is usually a disease of early reproductive life - the peak incidence is be- tween the ages of 15 and 35 years. BBDs are among prevalent strong risk factors for breast cancer. Today, it has been admitted that breast cancer is located 3-5 times more often in women with benign lesions of breast and 30-40 times more often if the women are suffering from nodulose form of mastopathy with signs of epithelial proliferation [4].

It is known that abnormal blood vessel outgrowth plays an important role in the genesis and development of various tumors, and growth of neoplastic masses is associated with formation of their own vessels due to pathological neovascularization [5]. J. Folkman [6] has shown that neoplastic tissues have a peculiar capacity to induce angiogenesis in the surrounding tissues, and lack of vessel formation can exclude neoplastic growth. It should be emphasized that angiogenesis is regulated by a balance between pro- and anti-angiogenic factors. 
Angiogenesis in invasive breast cancer is well documented [7], but relatively few studies have addressed the role of angiogenesis in pre-malignant disease or benign neoplasms where the switch of angiogenesis balance may also occurs during their development. "Angiogenic switch" is a crucial step for the progression of tumor from the benign to malignant state [8]. Though the benign states and breast cancers share many similar pathological processes, their angiogenic abilities are rather different. The angiogenic capacities are rare in fibrous or adipose tissue and in tissues from fibroadenomas, fibrocystic disease, and normal lobules, but it is pronounced in carcinomas and intraductal papillomas [9]. The molecular mechanisms responsible for maintenance of low angiogenic potential in benign lesions are still uncovered.

Limited proteolysis of extracellular proteins by matrix metalloproteinases (MMPs) and some serine proteases is an important step in the regulation of angiogenesis. Among the proteolytic degradation products derived from extracellular matrix proteins and hemostasis factors, a number of fragments have potent angiogenesis inhibiting properties [10]. One of them, angiostatin (AS), is an internal proteolytically derived fragment of plasminogen (Plg), spanning various numbers of its kringle domains. AS is considered to be one of the most powerful endogenous inhibitors of neovascularization. AS suppresses angiogenesis by inhibiting endothelial cell proliferation, migration and can even promote endothelial apoptosis [11-13]. As a rule, AS circulates in abundance in plasma of patients with different cancers and inflammatory states, however, the changes in blood concentrations of this molecule are not always consistent with the alterations of their tissue levels $[14,15]$. To our knowledge, no reports have examined content of Plg/AS in the breast benign neoplasms. In order to fill this gap, here we aimed to determine amounts of these proteins in benign noncancerous lesions of mammary gland. To check the hypothesis that local levels of AS and its precursor molecule could be related to abnormally increased rate of breast cell proliferation, we paid special attention on Plg/AS content in fibroadenomas with different proliferating potential. Evaluation of activities of the collagenolytic enzymes, which could be potentially responsible for Plg degradation and AS release in tissues of breast benign formations, was also among the tasks of this study.

\section{Materials and Methods}

Patients and tissue specimens. Breast tissue specimens were obtained from women with various BBDs (fibroadenoma, fibrocystic breast disease, breast cyst, $n=9$ for each type of disease) by surgical resection performed in certified Laboratory of Pathomorphology of Odessa Regional Oncology Center. The diagnoses were established histologically by experienced breast pathologists. Fibroadenoma nodules were additionally screened for ductal epithelial proliferative changes and sub-classified as nonproliferatious and proliferatious forms ( $n=5$ and 4, respectively), based on the criteria as described by Rosen et al. [16]. The size of surgical specimens was at least $0.5 \mathrm{~cm}^{3}$. The study protocol was prepared in accordance with international and local human research ethical standards. Informed consent was obtained from all patients before the beginning of the study. The samples of the surrounding healthy tissues were used as controls $(n=6)$. Tissue specimens were kept at $-80^{\circ} \mathrm{C}$ until they were transported on ice and frozen at $-20^{\circ} \mathrm{C}$ when received.

Reagents. Secondary anti-rabbit horseradish peroxidise (HRP)-conjugated IgG, bovine serum albumin (BSA), protease inhibitors, ethylenediaminetetraacetic acid (EDTA), Triton X-100, Tween-80, ammonium persulfate, tetrahydrochloride hydrate, tetramethylethylenediamine (TEMED), 3,3'-diaminobenzidine (DAB), non-fat dry milk, gelatine, Coomassie Briliant Blue R-250 were purchased from Sigma (USA); tris(hydroxymethyl)aminomethane, glycine, acrilamide, bis-acrilamide, sodium phosphates, sodium chloride were obtained from Helicon (Russian Federation); sodium dodecyl sulphate (SDS) were purchased from AppliChem (Germany); molecular weight markers (PageRuler Prestained Protein Ladder) were obtained from Fermentas (Germany). All other chemicals were of analytical reagent grade.

Protein sample preparation. Protein samples of normal and pathological breast tissues for further AS detection were prepared by grinding and homogenization of tissue specimens (weighted 100-150 mg) in ice-cold $50 \mathrm{mM}$ Tris-HCl buffer ( $\mathrm{pH} 7.4$ ), additionally containing $150 \mathrm{mM} \mathrm{NaCl}, 1 \%$ SDS, 2.5 mM EDTA, $6.5 \mu \mathrm{M}$ aprotinin, $1.5 \mu \mathrm{M}$ pepstatin A, $23 \mu \mathrm{M}$ leupeptin, $1 \mathrm{mM}$ phenylmethylsulfonyl fluoride, $5 \mu \mathrm{g} / \mathrm{ml}$ soybean trypsin inhibitor. Tissue:buffer ratio was taken equal 1:5 (m/v). For MMP analysis, tissue specimens were processed the same homog- 
enization procedures using of $50 \mathrm{mM}$ Tris- $\mathrm{HCl}(\mathrm{pH}$ 7.4), which contained $150 \mathrm{mM} \mathrm{NaCl}$ and was supplemented with serine proteinase inhibitors mentioned above (tissue:buffer $=1: 3, \mathrm{~m} / \mathrm{v}$ ). After homogenisation steps, samples were sonicated for approximately 30 sec with using of ultrasonic disintegrator Sartorius (Labsonic ${ }^{\circledR} \mathrm{M}$, Göttingen, Germany) and centrifuged at $16000 \mathrm{~g}$ for $45 \mathrm{~min}$ at $4{ }^{\circ} \mathrm{C}$. All supernatants were carefully removed and transferred into the clean Eppendorf tubes. The total protein concentration in each supernatant was determined spectrophotometrically by Stoscheck method measuring absorbance at 260, 280, and $320 \mathrm{~nm}$ as described elsewhere [17]. The samples were diluted 1:1 with non-reducing Laemmli Sample Buffer, frozen and stored at $-20{ }^{\circ} \mathrm{C}$ before analysis.

Immunoblotting. Protein samples $(50 \mu \mathrm{g} /$ track $)$ were run in $5-18 \%$ denaturing polyacrilamide gels (PAAG) and transferred onto nitrocellulose membrane (GE Healthcare, Amersham Bioscience) with $0.45 \mu \mathrm{m}$ pore diameter by means of electroblot. After transferring, membranes were blocked in $5 \% \mathrm{~m} / \mathrm{v}$ non-fat dry milk for $90 \mathrm{~min}$ at $37^{\circ} \mathrm{C}$ and probed with primary antibody, which were obtained as described previously $[15,18]$. Briefly, isolated and purified product of Plg limited digesting by porcine elastase, which comprises the first three kringle domains (K1-3), was used as an antigen for rabbit immunization. Polyclonal antibodies, purified on immunoaffine sorbent K1-3-sepharose, appeared to recognize AS-like proteolytic fragments of Plg as well as the parent molecule. Anti-AS/Plg antibody was diluted in phosphate buffer saline (PBS) and used in final concentration $5 \mu \mathrm{g} / \mathrm{ml}$. After overnight incubation at $4{ }^{\circ} \mathrm{C}$, membranes were washed five times with PBS, containing $0.05 \%$ Triton X-100 (PBST), and then incubated for $60 \mathrm{~min}$ with the HRP-conjugated secondary antibody diluted in PBST 1/3000. Then, unbound antibodies were removed by 7-times washes in PBST for 5 min each. Specific immunostaining was developed by incubation of membranes with $0.05 \%$ DAB in $50 \mathrm{mM}$ Tris- $\mathrm{HCl}$ buffer ( $\mathrm{pH} 7.4$ ), containing $0.01 \% \mathrm{H}_{2} \mathrm{O}_{2}$. Relative intensities of bands, correspondent to Plg and AS, were measured using densitometry software TotalLab TL120 (Nonlinear Inc, USA). Each trace was corrected for background by subtracting a tracing of nonreactive area on the blot. Antigens of various molecular weights were identified by extrapolation of plots of relative mobilities of prestained trans-blot proteins with known molecular weight (PageRuler Prestained Protein Ladder).
Gelatin zymography. It is generally accepted that zymographic tests of MMP activity have some advantages over immunologic assays due to lower costs, more rapid time of execution and the possibility of detection simultaneously multiple forms of MMPs [19]. For detection of MMP activities in the samples obtained from breast tissues, gelatine zymography was performed using SDS-PAAG electrophoresis with $7.5 \%$ separating and $4 \%$ stacking gels in the absence of reducing agents. The separating gel was copolymerized with heat-denatured gelatine $(5 \mathrm{mg} / \mathrm{ml})$ as enzyme substrate. Tissue extracts in the volumes, containing $50 \mu \mathrm{g}$ total protein, were loaded onto gelatine-PAAG slabs. After running, gels were washed twice with $2.5 \%$ Triton $\mathrm{X}-100$ in aqueous solution and then rinsed five times with ice-cold bidistilled water and incubated in $50 \mathrm{mM}$ Tris- $\mathrm{HCl}$ de-

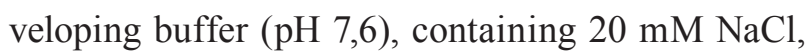
$5 \mathrm{mM} \mathrm{CaCl}_{2}, 1 \mathrm{mM} \mathrm{ZnCl}_{2}, 0.05 \%$ Triton X-100, and $0.02 \%$ Tween- 80 , at $37^{\circ} \mathrm{C}$ for $16 \mathrm{~h}$. Zymograms were stained with Coomassie Briliant Blue R-250 and destained with $30 \%$ methanol and $10 \%$ acetic acid in distilled water. The final gel had a uniform blue background except in those regions to which MMPs had migrated and cleaved the substrate, so bands of gelatine degradation could be seen as transparent areas against a blue background. Molecular weights were determined using standard pre-stained molecular weight markers.

Statistical analysis. The statistics were performed using non-parametric Mann-Whitney $U$-test. $\mathrm{Plg}$ and AS contents, evaluated by immunoblots, are expressed in arbitrary units (a.u.) and presented in histograms as medians. Statistical significance was defined as $P$ less than 0.05 .

\section{Results and Discussion}

Polyclonal antibodies used for immunoblot analysis reacted with bands, the approximate molecular weights of which were 90 and $50 \mathrm{kDa}$ (Fig. 1). $M_{r}$ values of these bands correspond to native plasminogen $\left(\mathrm{M}_{\mathrm{r}} 92-93 \mathrm{kDa}\right)$ and AS-like fragment $\left(\mathrm{M}_{\mathrm{r}} 45-50 \mathrm{kDa}\right)$, consisting of first four kringle domains (K1-4 or K1-4.5). Only trace amounts of immunoreactivity were observed in protein samples obtained from histologically normal breast tissues, used as control in the present study. In contrast, abundance of two major immunoreactive polypeptide bands is found in the samples prepared from benign tissue lesions. Western blot of samples produced from fibroadenoma nodules shown that inten- 
sities of Plg/AS band immunostaining depend on the proliferation potential of neoplasm. In fibroadenomas with increased proliferative rate, weak specific immunoreactivity is observed, while non-proliferatious neoplasms represent more intense Plg/AS immunostaining. This observation can be of peculiar importance because levels of these proteins could reflect development of regressive changes in breast tissues or transformation of cells, composing a tumor.

In order to quantify results of immunoblotting, densitometric analysis was performed and intensities of immunoreactivity of Plg and AS bands as medians of arbitrary units are presented in Fig. 2. It was shown that levels of AS isoform were correlated with Plg content in both normal and pathological tissues. However, in mastopathy, Plg and AS levels were found to be 4.7- and 6.7-fold higher than those for unchanged tissues respectively $(P<0.05)$. Significant increase in both Plg and AS contents was also found in cysts as compared with healthy tissues (3.7and 4 -folds respectively, $P<0.05$ ). In fibroadenoma (benign neoplasm condition), Plg and AS abundance was 3.5- and 3.7-fold higher in the case of non-proliferative form as compared with control $(P<0.05)$. In order to relate our data with disease features, we measured Plg/AS levels in samples prepared from fibroadenoma nodules with signs of hyperproliferation. It is of interest that averaged levels of Plg and its $50 \mathrm{kDa}$ proteolytic fragment in fibroadenoma with evident proliferative changes appeared to be respectively 3.8- and 5.3-fold lower than that of nonproliferatious form of this neoplasm.

Gelatine zymography of the samples of healthy mammary tissues and breast benign masses was performed to assess activity of MMPs (gelatinases). It is important to note that serine protease inhibitors were added into the homogenization buffer in order to exclude participation of these enzymes in

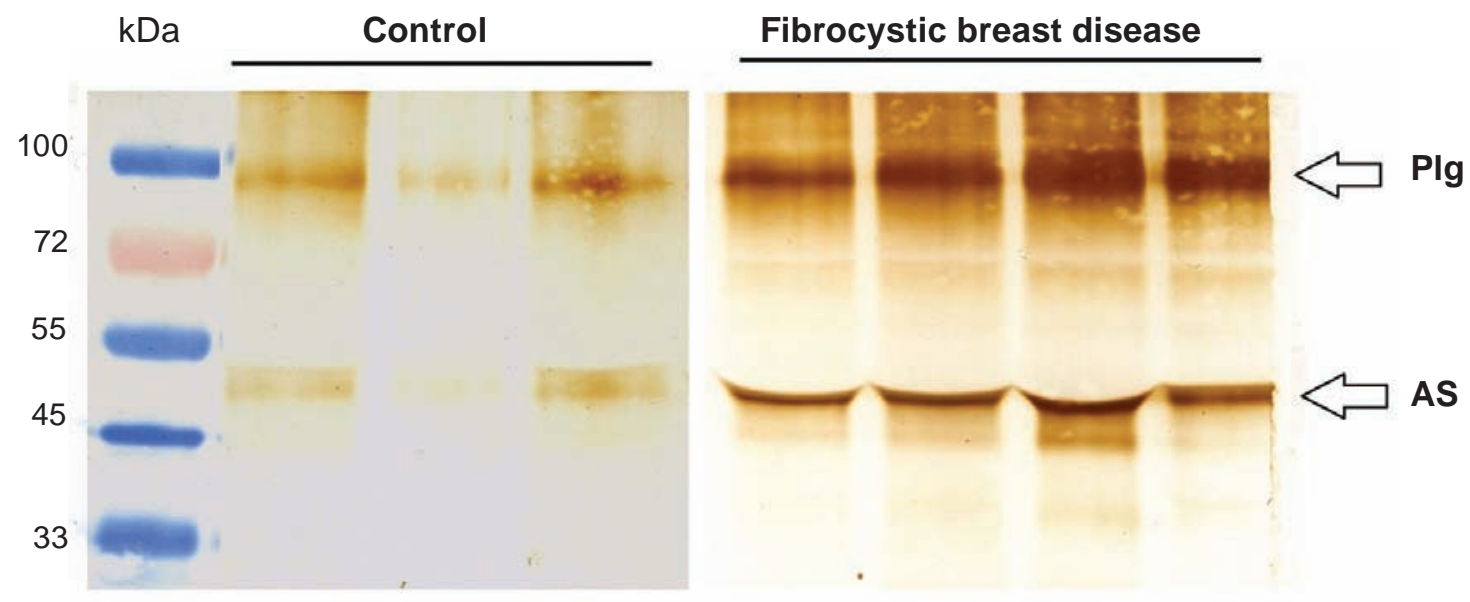

Breast cyst

Fibroadenoma

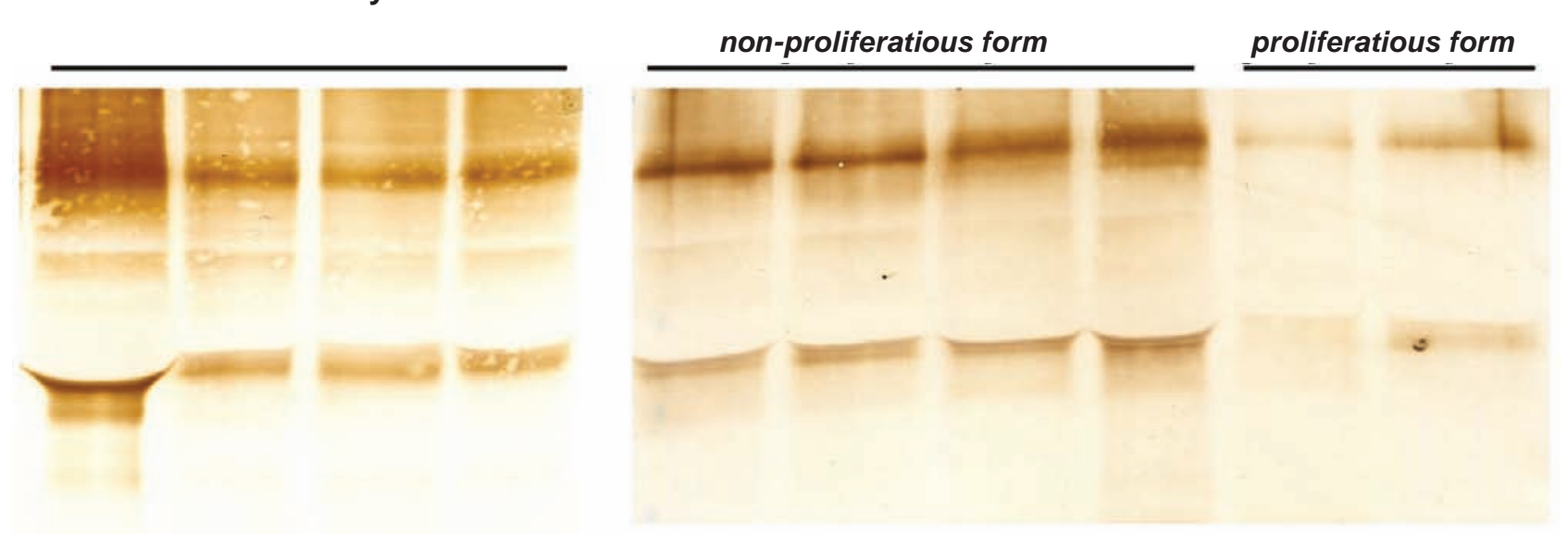

Fig. 1. Immunoblots of protein samples prepared from mammary tissues of female patients with various breast benign diseases and healthy control tissues 
$\boldsymbol{A}$

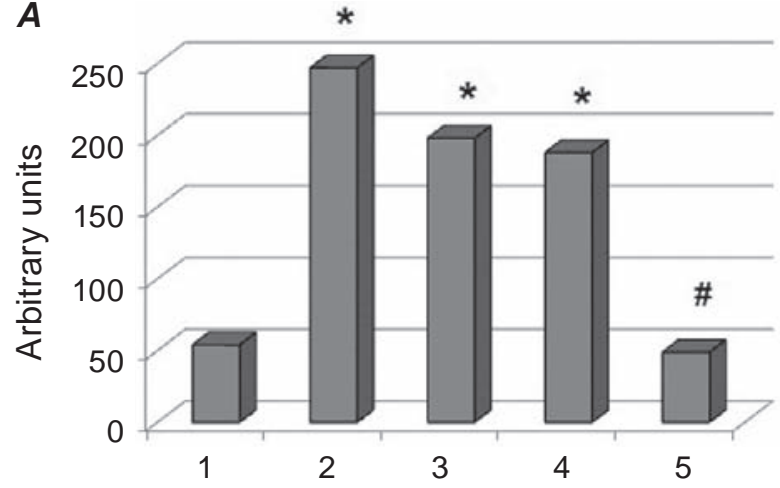

B

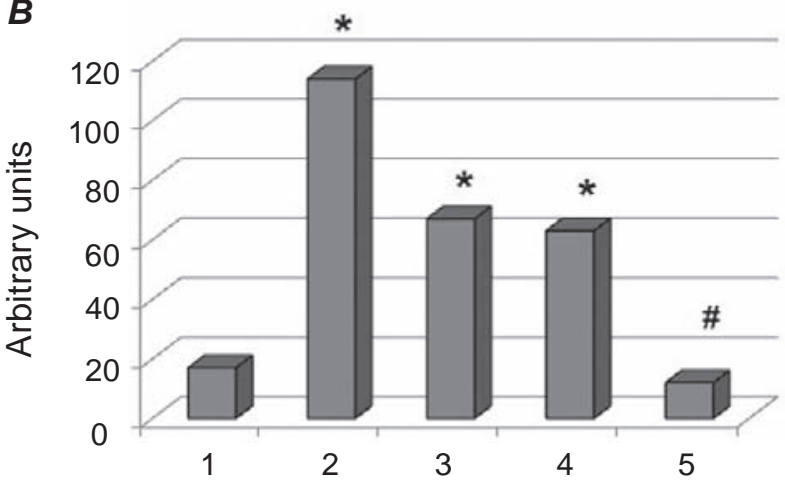

Fig. 2. Results of densitometry analysis of plasminogen (A) and angiostatin (B) detected by immunoblotting (data are expressed as medians): 1 - control $(n=6), 2$ - fibrocystic disease $(n=9), 3$ - breast cyst $(n=9)$, 4 -fibroadenoma (non-proliferatious form, $n=5$ ), 5 -fibroadenoma (proliferatious form, $n=4$ ). ${ }^{*} P<0.05$ as compared to control (Mann-Whitney U-test); \# $P<0.05$ as compared to non-proliferatious form of fibroadenoma (Mann-Whitney U-test)

gelatine digesting, thus eliminating possible appearance of false-positive results. As shown in Fig. 3, A, there was no collagenolytic activity in homogenates isolated from normal breast tissues. In contrast, in most samples prepared from breast benign lesions, the single abundant proteolytic activity was detected as band with approximate $\mathrm{M}_{\mathrm{r}} 90 \mathrm{kDa}$, which is corresponds to MMP-9. Though it has been previously established that MMP-2 and -9 are major gelatinolytic protease expressing in breast tumors and circulating in blood of cancer patients $[19,20]$, we were failed to reveal active MMP-2 $\left(\mathrm{M}_{\mathrm{r}} 72 \mathrm{kDa}\right)$ isoform in benign mammary masses.

The application of immunochemical methods (ELISA, Western blot) for AS determination in patient's blood plasma or serum is a commonly used procedure. However, at present, little is known about the localization of AS in human tissues. Also, there is lack of information concerning local levels and physiological significance of AS in BBDs. Here, we for the first time have assessed contents of AS and its parent molecule (Plg) in breast tissues of women with fibrocystic disease, cysts, and fibroadenomas.

It is known that regulation of angiogenesis is governed by a fine equilibrium between pro-angiogenic factors (vascular endothelial growth factor VEGF, fibroblast growth factor - FGF, platelet-derived growth factor - PDGF, transforming growth factor - TGF) and anti-angiogenic factors such as thrombospondin, pigment epithelium-derived factor - PEDF, endostatin, tumstatin. In adults, blood vessel formation is tightly controlled by "angiogenic balance", while angiogenesis is well-addressed to be

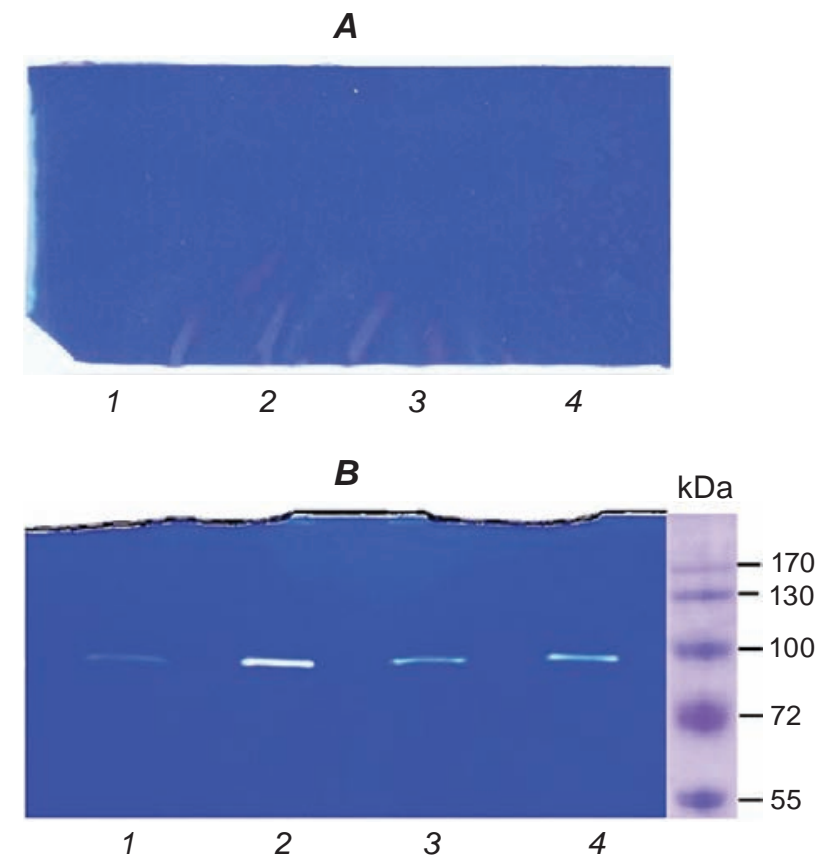

Fig. 3. Gelatin zymography of protein samples obtained from normal mammary gland tissues (A, 1-4 numbers of samples) and benign breast masses ( $B: 1$ and 2 - fibrocystic disease, 3 and 4 - breast cysts)

essential for solid tumors, including breast cancers, to grow [21]. At present, a whole range of angiogenesis inhibiting fragments of matrix proteins and coagulation related proteins have been recognized, such as angiostatin, endostatin, tumstatin, alphastatin, thrombospondin fragments and many others [10]. Plg, catalytically non-active proenzyme, contributes to angiogenesis, but plays a role of double- 
faced Janus. On the one hand, Plg can be converted into active proteinase plasmin, and when bound to specific cell-surface and extracellular matrix receptors, plasmin participates in degradation of extracellular matrices during cell migration, tissue remodelling, tumor cell invasion, and inflammation. On the other hand, Plg is also a precursor for a group of anti-angiogenic molecules, AS [22]. They represents a family of proteolytic fragments of $\mathrm{Plg}$, consisting of different number of kringle domains as well as single kringle domains (K1-3, K1-4, K1-4.5, K1-5, K2-3, K5 are definitely described) [23]. It has been reported that AS isoforms are generated from Plg by limited proteolysis-related enzymes, such as plasmin, cathepsins, prostate-specific antigen, pancreatic and neutrophil elastase [24]. Among the proteases that are involved both in tumor angiogenesis and AS generation, the members of MMP family (MMP-1, $-2,3-,-7,-9,12,14$, and -19) has been extensively studied [25]. AS blocks proliferation, migration, differentiation and tube formation of endothelial cells, therefore suppressing microvessel formation, tumor progression, and metastasis [26]. It is known that human AS inhibits the growth of transplanted human and murine primary tumors in mice and causes human primary carcinomas to regress to a dormant state by a net balance of tumor cell proliferation and apoptosis. For example, the full kringles of Plg (K1-5) caused total regression of human MDAMB-231 breast tumor xenografted in mice, which was correlated with a drastic decrease of functional neovascularization into the tumors and inhibition of metastatic dissemination [27]. Pronounced antiinflammatory effects of AS are documented and extensively studied as well $[28,29]$.

Results of Western blots demonstrate simultaneous elevation of $\mathrm{Plg}$ and its proteolytic fragment levels in breast benign lesions (Fig. 1). The interpretation of this result may be that cells of benign tissue lumps can expose a number of molecules, which participate in Plg/AS binding with cellular surface. A variety of proteins, including actin, annexin II, S100A10, cytokeratin 8 , tetranectin and $\alpha$-enolase have been identified as potential Plg receptors on the surface of certain types of human breast cancer cells [30]. AS appeared to effectively interact with some Plg receptors. For example, Dudani et al. [31] have shown that surface-associated $\beta$-actin can bind both Plg and AS K1-4 $\left(K_{d} \sim 140 \mathrm{nmol} / \mathrm{L}\right)$. It is thought that AS, competing for binding sites with proenzyme, can inhibit Plg conversion into active proteinase and thus modulate plasmin-dependent processes such as cell migration/movement, extracellular matrix remodelling.

In biological fluids or tissues of patients with different pathologies, a heterogeneous mixture of $\mathrm{Plg}$ fragments is often observed, with patterns that also varied between patients [32]. In our study, ASlike fragment $50 \mathrm{kDa}$ appears to be the principal Plg fragment, which is solely produced in breast tissues. Therefore, it is most likely that certain type of proteinases contributes to Plg processing in mammary gland. A number of papers highlights that Plg fragmentation in breast tumors is usually associated with MMPs, and MMP-2 and -9 are the most important ones $[19,20]$. Although neither normal nor pathological breast tissues expressed any MMP-2 enzymatic activity, presence of activated MMP-9 is obviously demonstrated in the samples of fibrocystic and cyst masses (Fig. 3). Our data suggesting the absence of MMP-2 activity in mastopathy or cyst masses are in agreement with the previous reports [33], indicating MMP-2 to be constituent proteinase of rather malignant tumors responsible for cancer cell invasion and metastasis. In our study, we were not focused on measuring gelatinase activities in fibroadenoma, nevertheless, a number of earlier researches indicates that active MMP-2 and MMP-9 infrequently occur in low levels in benign tumor tissue extracts $[19,34]$. However, active MMP-2 occurs more frequently and at higher levels in malignant carcinoma tissue as compared with benign fibroadenoma tissue. Dramatically elevated levels of the both gelatinases are found in blood of breast cancer patients compared to benign mammary pathologies and healthy controls [35]. MMPs can be released by different cells, like neutrophils, macrophages or other inflammatory cells that need to digest ECM to access organ parenchymas. Since macrophages are the major population of infiltrating cells in tumor stroma, so it is possible that they may have a role in regulating of angiogenesis through MMP secretion and Plg conversion into AS [36, 37].

Hyperplasia is recognized to be a benign breast condition where some breast cells begin to divide more quickly than normal, however staying differentiated and saving non-cancerous phenotype. Pathophysiological impact and clinical significance of elevated activity of MMP-9 and Plg/AS expression in breast benign lesions are uncertain. Earlier, Chung et al. [37] have shown that up-regulation of MMP-2 and -9 and increased AS generation correlate with vascu- 
lar stiffening, impaired angiogenesis, and endothelial dysfunction in kidneys. In the same way, activation of MMP-9 and elevation of Plg-derived protein levels in fibrocystic lesions and breast cyst tissues can be at least partially responsible for angiogenesis impairments and vascular abnormalities typical for breast benign lesions. It remains still unknown if excessive amounts of AS contribute to the development of connective tissue sclerosis, disturbances of local circulation, and progressive atrophy, which occur in fibrous cysts [38]. Here, it is assumed that AS can play a potential role in regulating proliferation of epithelial or mesenchimal elements in fibroadenoma. Decreased levels of Plg/AS discovered in breast tissues of patients with proliferatious form of fibroadenoma may be related to proliferative capacities of the cells. However, it remains to be elucidated if changed AS levels could be considered either as consequences or as causative factors, which are necessary for benign tumor cells to acquire and sustain high proliferative potential. Further work is needed to examine the precise mechanisms and molecular orchestration involved in AS formation in mammary gland tissues and to establish whether AS has a key independent role in the development of proliferative and regressive changes within breast tissues under benign conditions.

Acknowledgments. The support of Odessa Regional Oncology Center is gratefully acknowledged.

\section{ВМІСТ ПЛАЗМІНОГЕНУ ТА АНГІОСТАТИНІВ У ТКАНИНАХ ДОБРОЯКІСНИХ УТВОРЕНЬ МОЛОЧНОЇ ЗАЛОЗИ ЖІНОК}

\section{А. О. Тихомиров 1 І. Л. Вовчук ${ }^{2}$, T. В. Гриненко ${ }^{1}$}

${ }^{1}$ Інститут біохімії ім. О. В. Палладіна НАН України, Київ;

${ }^{2}$ Одеський національний університет ім. I. І. Мечникова, Україна; e-mail: artem_tykhomyrov@ukr.net

Відомо, що доброякісні утворення молочної залози характеризуються відносно низьким рівнем ангіогенезу. Активація ангіогенезу за гіперпроліферативних захворювань молочної залози може бути пов'язана з подальшим розвитком патології та підвищеним ризиком злоякісної трансформації. Однак молекулярні механізми, що лежать в основі регуляції ангіогенезу в доброякісних новоутвореннях молочної залози, залишаються недостатньо вивченими. Метою роботи було визначити вміст плазміногену та його протеолітичних фрагментів (ангіостатинів) у тканинах молочної залози за мастопатії та кістозної хвороби, а також у доброякісних новоутвореннях (фіброаденомах). Детекцію плазміногену та ангіостатинів проводили за допомогою імуноблотингу з подальшим кількісним денситометричним аналізом. Показано, що рівень плазміногену в тканинах молочної залози за мастопатії, кісти та непроліферуючої форми фіброаденоми у 4,7, 3,7 і 3,5 раза відповідно перевищує цей показник у нормальних тканинах (контроль). Вміст протеолітичного фрагмента плазміногену з молекулярною масою 50 кДа (ангіостатину) в цих доброякісних утвореннях виявився відповідно у 6,7, 4,0 і 3,7 раза вищим за контрольний рівень. Зростання концентрації ангіостатину може відбуватися внаслідок розщеплення плазміногену тканинною матричною металопротеїназою-9, активну форму якої виявлено методом желатинової зимографії за фіброзно-кістозної хвороби та кісти. Натомість, у тканинах проліферативної форми фіброаденоми рівень плазміногену та ангіостатину виявився відповідно у 3,8 і 5,3 раза нижчим порівняно 3 непрогресуючою неоплазією. Наведені результати дозволяють припустити, що ангіостатини як потужні інгібітори ангіогенезу та протизапальні агенти можуть відігравати важливу роль у патогенезі дисплазій молочної залози. Подальші дослідження необхідні для оцінки діагностичного та клінічного значення цих протеїнів для прогнозування та терапії доброякісних захворювань молочної залози.

К л ю чо в $\quad$ слов а: плазміноген, ангіостатин, матричні металопротеїнази, ангіогенез, доброякісні захворювання молочної залози, мастопатія, кіста молочної залози, фіброаденома. 


\section{СОДЕРЖАНИЕ ПЛАЗМИНОГЕНА И АНГИОСТАТИНОВ В ТКАНЯХ ДОБРОКАЧЕСТВЕННЫХ ОБРАЗОВАНИЙ МОЛОЧНОЙ ЖЕЛЕЗЫ ЖЕНЩИН}

\author{
А. А. Тихомиров 1 , И. Л. Вовчук ${ }^{2}$, \\ T. В. Гриненко
}

\author{
${ }^{1}$ Институт биохимии им. А. В. Палладина \\ НАН Украины, Киев; \\ ${ }^{2}$ Одесский национальный университет \\ им. И. И. Мечникова, Украина; \\ e-mail: artem_tykhomyrov@ukr.net
}

Известно, что доброкачественные образования молочной железы характеризуются относительно низким уровнем ангиогенеза. Активация ангиогенеза при гиперпролиферативных заболеваниях молочной железы может быть связана с дальнейшим развитием патологии и повышенным риском злокачественной трансформации. Однако молекулярные механизмы, лежащие в основе регуляции ангиогенеза в доброкачественных новообразованиях молочной железы, остаются недостаточно изученными. Целью данной работы было определить содержание плазминогена и его протеолитических фрагментов (ангиостатинов) в тканях молочной железы при мастопатиях и кистозной болезни, а также в доброкачественных новообразованиях (фиброаденомах). Детекцию плазминогена и ангиостатинов проводили с помощью иммуноблоттинга с дальнейшим количественным денситометрическим анализом. Показано, что уровень плазминогена в тканях молочной железы при мастопатии, кисте и непролиферирующей форме фиброаденомы в 4,7, 3,7 и 3,5 раза соответственно превышал этот показатель в нормальных тканях (контроль). Содержание протеолитического фрагмента плазминогена с молекулярной массой 50 кДа (ангиостатина) в этих доброкачественных образованиях оказалось соответственно в 6,7, 4 и 3,7 раза выше по сравнению с контрольным уровнем. Возрастание концентрации ангиостатина может происходить вследствие расщепления плазминогена тканевой матричной металлопротеиназой-9, активную форму которой выявлено методом желатиновой зимографии при фиброзно-кистозной болезни и кисте. В то же время в тканях пролиферативной формы фиброаденомы уровень плазминогена и ангиостатина оказался соответ- ственно в 3,8 и 5,3 раза ниже по сравнению с непрогрессирующей неоплазией. Представленные результаты позволяют предположить, что ангиостатины, будучи мощными ингибиторами ангиогенеза и противовоспалительными агентами, могут играть важную роль в патогенезе дисплазий молочной железы. Дальнейшие исследования необходимы для оценки диагностического и клинического значения этих протеинов при прогнозировании и терапии доброкачественных заболеваний молочной железы.

К л ю че вы е ло в а: плазминоген, ангиостатин, матричные металлопротеиназы, ангиогенез, доброкачественные заболевания молочной железы, мастопатия, киста молочной железы, фиброаденома.

\section{References}

1. Mannello F., Tonti G.A. Benign breast diseases: classification, diagnosis, and management. Oncologist. 2006;11(10):1132-1134.

2. Norwoord S. L. Fibrocystic breast disease. An update and review. J. Obstet. Gynecol. Neonatal. Nurs. 1990;19(2):116-121.

3. Houssami N., Irwig L., Ung O. Review of complex breast cysts: implications for cancer detection and clinical practice. ANZ J. Surg. 2005;75(12):1080-1085.

4. El-Wakeel H., Umpleby H.C. Systematic review of fibroadenoma as a risk factor for breast cancer. Breast. 2003;12(5):302-307.

5. Kerbel R. S. Tumor angiogenesis. N. Engl. J. Med. 2008;358(19):2039-49.

6. Folkman J. Tumor angiogenesis: therapeutic implications. N. Engl. J. Med. 1971;285(21):11821186.

7. Bos R., van Diest P. J., de Jong J. S., van der Groep P., van der Valk P., van der Wall E. Hypoxia-inducible factor-1alpha is associated with angiogenesis, and expression of bFGF, PDGF-BB, and EGFR in invasive breast cancer. Histopathology. 2005;46(1):31-36.

8. Bluff J. E., Menakuru S. R., Cross S. S., Higham S. E., Balasubramanian S. P., Brown N. J., Reed M. W., Staton C. A. Angiogenesis is associated with the onset of hyperplasia in human ductal breast disease. $\mathrm{Br}$. J. Cancer. 2009;101(4):666-672.

9. Azzopardi J. G. Benignand malignant proliferative epithelial lesions of the breast; a review. Eur. J. Cancer Clin. Oncol. 1983;19(12):1717-1720. 
10. Nyberg P., Xie L., Kalluri R. Endogenous inhibitors of angiogenesis. Cancer Res. 2005;65(10):3967-79.

11. O’Reilly M. S., Holmgren L., Shing Y., Chen C., Rosenthal R. A., Cao Y., Moses M., Lane W. S., Sage E. H., Folkman J. Angiostatin: a circulating endothelial cell inhibitor that suppresses angiogenesis and tumor growth. Cold Spring Harb. Symp. Quant. Biol. 1994;59:471-482.

12. Wahl M. L., Kenan D. J., Gonzalez-Gronow M., Pizzo S. V. Angiostatin's molecular mechanism: aspects of specificity and regulation elucidated. J. Cell Biochem. 2005;96(2):242-261.

13. Cho C.F., Chen P. K., Chang P. C., Wu H. L., Shi G. Y. Human plasminogen kringle 1-5 inhibits angiogenesis and induces thrombomodulin degradation in a protein kinase A-dependent manner. J. Mol. Cell. Cardiol. 2013;63:79-88.

14. Szarvas T., Jäger T., Laszlo V., Kramer G., Klingler H. C., vom Dorp F., Romics I., Ergün S., Rübben H. Circulating angiostatin, bFGF, and Tie2/TEK levels and their prognostic impact in bladder cancer. Urology. 2012;80(3):13-18.

15. Tykhomyrov A. A., Nedzvetsky V. S., Bardachenko N. I., Grinenko T. V., Kuryata O. V. Statin treatment decreases serum angiostatin levels in patients with ischemic heart disease. Life Sci. 2015;134:22-29.

16. Rosen P. P. Pathological examination of breast specimens. In: Rosen PP, ed. Breast Pathology. Philadelphia, PA: LippincottRaven; 1997:837872.

17. Stoscheck C. M. Quantitation of protein. Methods Enzymol. 1990;182:50-68.

18. Tykhomyrov A. A., Yusova E. I., Diordieva S. I., Corsa V. V., Grinenko T. V. Production and characteristics of antibodies against K1-3 fragment of human plasminogen. Biotechnologia Acta. 2013;6(1):86-96.

19. La Rocca G., Pucci-Minafra I., Marrazzo A., Taormina P., Minafra S. Zymographic detection and clinical correlations of MMP-2 and MMP-9 in breast cancer sera. Br. J. Cancer. 2004;90(7):1414-1421.

20. Hanemaaijer R., Verheijen J. H., Maguire T. M., Visser H., Toet K., McDermott E., O’Higgins N., Duffy M. J. Increased gelatinase-A and gelatinase-B activities in malignant vs. benign breast tumors. Int. J. Cancer. 2000;86(2):204207.
21. Tonini T., Rossi F., Claudio P.P. Molecular basis of angiogenesis and cancer. Oncogene. 2003;22(42):6549-6556.

22. Zhernosekov D. D., Iusova E. I., Grinenko T. V. Role of plasminogen/plasmin in functional activity of blood cells. Ukr. Biokhim. Zhurn. 2012;84(4):5-19.

23. Doll J. A., Soff G. A. Angiostatin. Cancer Treat. Res. 2005;126:175-204.

24. Gately S., Twardowski P., Stack M. S., Cundiff D. L., Grella D., Castellino F. J., Enghild J., Kwaan H. C., Lee F., Kramer R. A., Volpert O., Bouck N., Soff G. A. The mechanism of cancer-mediated conversion of plasminogen to the angiogenesis inhibitor angiostatin. Proc. Natl. Acad. Sci. USA. 1997;94(20):10868-10872.

25. Heissig B., Hattori K., Friedrich M., Rafii S., WerbZ. Angiogenesis: vascular remodeling of the extracellular matrix involves metalloproteinases. Curr. Opin. Hematol. 2003;10(2):136-141.

26. Xu R., Sun X., Tse L. Y., Li H., Chan P. C., Xu S., Xiao W., Kung H.F., Krissansen G. W., Fan S. T. Long-term expression of angiostatin suppresses metastatic liver cancer in mice. Hepatology. 2003;37(6):1451-1460.

27. Galaup A., Magnon C., Rouffiac V., Opolon P., Opolon D., Lassau N., Tursz T., Perricaudet M., Griscelli F. Full kringles of plasminogen (aa 1-566) mediate complete regression of human MDA-MB-231 breast tumor xenografted in nude mice. Gene Ther. 2005;12(10):831-842.

28. Mu W., Long D. A., Ouyang X., Agarwal A., Cruz P. E., Roncal C. A., Nakagawa T., Yu X., Hauswirth W. W., Johnson R. J. Angiostatin overexpression is associated with an improvement in chronic kidney injury by an anti-inflammatory mechanism. Am. J. Physiol. Renal Physiol. 2009;296(1):145-152.

29. Perri S. R., Annabi B., Galipeau J. Angiostatin inhibits monocyte/macrophage migration via disruption of actin cytoskeleton. FASEB J. 2007;21(14):3928-3936.

30. Stillfried G. E., Saunders D. N., Ranson M. Plasminogen binding and activation at the breast cancer cell surface: the integral role of urokinase activity. Breast Cancer Res. 2007;9(1):1-11.

31. Dudani A. K., Ben-Tchavtchavadze M., Porter S., Tackaberry E. Angiostatin and plasminogen share binding to endothelial cell surface actin. Biochem. Cell. Biol. 2005;83(1):28-35. 
32. Migita T., Oda Y., Naito S., Morikawa W., Kuwano M., Tsuneyoshi M. The accumulation of angiostatin-like fragments in human prostate carcinoma. Clin. Cancer Res. 2001;7(9):27502756.

33. Jezierska A., Motyl T. Matrix metalloproteinase-2 involvement in breast cancer progression: a mini-review. Med. Sci. Monit. 2009;15(2):32-40.

34. Shah F. D., Shukla S. N., Shah P. M., Shukla H. K., Patel P. S. Clinical significance of matrix metalloproteinase 2 and 9 in breast cancer. Indian J. Cancer. 2009;46(3):194-202.

35. Ranuncolo S. M., Armanasco E., Cresta C., Bal De Kier Joffe E., Puricelli L. Plasma MMP-9 (92 kDa-MMP) activity is useful in the followup and in the assessment of prognosis in breast cancer patients. Int. J. Cancer. 2003;106(5):745751.
36. Xu Z., Shi H., Li Q., Mei Q., Bao J., Shen Y., Xu J. Mouse macrophage metalloelastase generates angiostatin from plasminogen and suppresses tumor angiogenesis in murine colon cancer. Oncol. Rep. 2008;20(1):81-88.

37. Chung A. W., Yang H. H., Sigrist M. K., Brin G., Chum E., Gourlay W. A., Levin A. Matrix metalloproteinase-2 and -9 exacerbate arterial stiffening and angiogenesis in diabetes and chronic kidney disease. Cardiovasc. Res. 2009;84(3):494-504.

38. Mnihovich M. V., Ternov M. M., Miglyas V. G. Precancer and breast cancer: light and electron assessment of extracellular matrix, angiogenesis and the microenvironment cell. Pathologia. 2011;8(1):36-41.

Received 14.07.2015 